\title{
Construction and Significance in Shakespearean Drama
}

\section{Keith Brown}

\section{(2) OpenEdition}

\section{Journals}

\section{Electronic version}

URL: http://journals.openedition.org/shakespeare/1320

DOI: 10.4000/shakespeare.1320

ISSN: 2271-6424

\section{Publisher}

Société Française Shakespeare

\section{Printed version}

Date of publication: 1 November 1989

Number of pages: 129-144

\section{Electronic reference}

Keith Brown, "Construction and Significance in Shakespearean Drama », Actes des congrès de la Société française Shakespeare [Online], 7 | 1989, Online since 01 January 2007, connection on 30 April 2019. URL : http://journals.openedition.org/shakespeare/1320 ; DOI : 10.4000/shakespeare.1320 


\title{
Société Française Shakespeare
}

\author{
Actes des Congrès \\ 1985 - 1986 - 1987
}

\section{LA FOLIE}

\section{SHAKESPEARE ET LES ARTS \\ LE TRAGIQUE}




\section{CONSTRUCTION AND SIGNIFICANCE IN SHAKES- PEAREAN DRAMA}

Keith BROWN

It is the purpose of this paper to argue that Shakespeare is a renaissance artist-in a sense to which too little attention has, as yet, been paid. But the point will perhaps best be made if we first consider certain of the changes which have taken place in our general picture of the literary art of the English renaissance, over the past thirty years or so.

Looking back, it is by now clear that in some respects our picture of the history of English renaissance literature began radically to alter in the nineteenfifties, after Kent Hieatt's celebrated demonstration of the elaborate correlation between the shape of Spenser's Epithalamion and the position of the heavens on the poet's wedding day ${ }^{1}$. Not that Hieatt's discovery was generally felt to be good news : the latent romanticism of mid-twentieth century literary zsthetics made it rather shocking that a major poet, in a major poem, should ever have "descended" to such detailed involvement with mere numerical calculation. Even more distasteful for many was the realisation that equally strange numerical possibilities mightalso need probing in other major texts of the period. But the cat was now out of the bag, and clearly someone had to pursue it : after Hieatt, it was simply no longer safe to assume that among Shakespeare's contemporaries an interest in number symbolism was the concern only of the quaint or the untalented. Over the past quarter-century a variety of scholars, braving their colleagues' understandable unease, have therefore felt their way forward into the tricky terrain of numerical and numerological explication of renaissance texts ${ }^{2}$. And the necessary background to such inquiries has been made much better known through such studies as Christopher Butler's book on Renaissance Number Symbolism. Today it seems fair to say that - within limits - awareness of the possibilities of number-symbolism is cautiously allowed to be at least a valid secondary intellectual tool in the kit of any analyst of nondramatic renaissance literary texts. Recently, an unexpectedly plausible case has been made for the presence of a numerological element even in Julius Caesar ${ }^{3}$.

By taking the king, moreover, Hieatt had clearly also taken the rest of the pieces on the board. If a writer of Spenser's standing would go to the extreme of 
building difficult numerical significances into even one major poem, was it not prima facie likelier still that he would often build simpler non-numerological - but still consciously significant - "architectural" patternings and structures into his compositions, too ? And might not his contemporaries, the mainstream writers, not just the fringe eccentrics, be expected to be doing the same? Such possibilities were not merely the logical-seeming implication of one textual discovery by Kent Hieatt ; the increasingly detailed picture that was developing of the general climate of ideas in Tudor and early Stuart England already pointed the same way.

It was, after all, an age in which it was natural to reason by analogy, and in which the analogy between the artist and his creator was fully grasped. Familiarity with Pythagorean ideas, and with the doctrine that God had created the world «by number, measure and weight», enabled the Renaissance to see the world as «God"s poem», and made it natural to view the Divine harmony of the Universe as the highest manifestation of music, the supreme paradigm of art. The poet, giving to airy nothing a local habitation and a name, and boasting half-seriously that his creations could also stand against Time, was perfectly conscious of following - if at an infinite remove - the pattern of that greater Maker who had coalesced the world out of empty Chaos, and set the first man to name His creatures. In such a climate, it would be natural for any serious poet to tend to develop a peculiar degree of self-consciousness about structural questions ; and for such self-consciousness to reflect more overtly «spatial» ways of thinking about literary form than is perhaps normal today. (That this actually happened can be seen, for example, in Drayton's matter-of-fact justification of a particular type of eight-line stanza, comparing its rhyme-scheme to the proportions of a Tuscan column 4 . For of course the kind of cosmological considerations just adduced meant that it was also natural to regard architecture, with its concern for strength, stability and right proportion, as another prime paradigm of art).

Perhaps then, in the discussion of renaissance literature, our familiar critical talk about "structure"/'design'/'proportion'/'architectonic' and the like, actually needed to be taken with the same unexpected literalness that the notion of the «numbers» of poetry had also turned out to require ? Once again, the hunch has proved fruitful : over the past thirty years, increasing alertness to the potential of structure and configuration in Renaissance texts for forming a separate, consciouslysignificant element within the total meaning of any given work, has come permanently to mark the way we see the literature of the period. Our awareness of the association of centrality with the idea of sovereignty is one obvious case in point.

Naturally these developments have met resistance. (As a recent contributor to ENGLISH ruefully noted in another context, there is an older generation of academic critics who seem haunted by needless fear that their heirs secretly wish to dismantle human consciousness to about the level of a mechanical computer). Until recently, scomfully impatient references to «line-counting and all the rest of it» resounded at many an academic literary conference. Yet in reality all we have been seeing has been the next phase of a progressive sophistication in critical thinking that 
has been going on since the last century, and of which older scholars' own work also formed a part.

This evolution is perhaps most simply seen in discussions of the long poem. Nineteenth century criticism tended to regard long poems as something squeezed by the pressure of inspiration out of the poet's mind like a ribbon of celestial toothpaste ; and with a presumed lack of internal structure that made them quite as difficult to get hold of or pick up. All that could really be done with such lengths of verse, was to analyse the ingredients, and give one's personal reactions to flavour or moral taste. But then came the successive development of new intellectual tools which, by helping critics to structure their own responses more tidily, also began to clarify - irrespective of length - the latent articulation of the texts they faced. For some fifty years, advances in science - in our understanding of human psychology and of the nature of language - really underlay this critical progress : "close reading", explorations of the workings of myth and symbol, and "Empsoniam ambiguity" were all among its fruits. These were not small gains. But a psycholinguistic critical tradition of this kind, of course, necessarily focusses on those orderings of a literary text that can only be fully developed intuitively or subconsciously. - Hence, the familiar exaggerations of the Intentional Fallacy doctrine : blithely insisting, with a hey derry-da, on the irrevelance of questions of "authorial intention" to proper critical response. The realisation of the impossibility of maintining that stance in the face of renaissance work whose consciously symbolic structure is wholly entwined with other aspects of its meaning, thus jarred on many, precisely because it did put "authorial intention" so firmly back in the picture again.

Yet the basic duty of the New Critic was to try to integrate the full totality of any text into his analysis or reading of it. And as William Empson tirelessly pointed out in the $1950 \mathrm{~s}$, that frequently requires taking at least tacit account of some aspect of the original author's apparent intentions. Any investigation of the often formalistic mentality with which literary composition was approached in the renaissance, essentially completes the New Critic's programme for him. It was an inevitable intellectual development, not an æsțhetic absurdity or betrayal.

As already noticed above, however, such 'structural' investigation has so far been focussed more upon the non-dramatic poetry of the English renaissance than on the parallel wealth of play-texts. One good reason for this, of course, is the known slowness of the Elizabethans and Jacobeans themselves in accepting contemporary theatre-scripts as "literature" : the situation was very like that we see today as regards TV-scripts. Clearly, in such a climate there was very little reason for the average playwright to work any very elaborate formal scheme into his.dramas, and so far investigation seems to confirm the suspicion that they generally did not do so. With 
Shakespeare, though, one might expect the case to be rather different : after all, he relatively early became the leading dramatist of his day, and his concern for his literary rather than his stage reputation seems suggested by the replacement of the Bad Quarto of Hamlet by a good new text too long for the stage. Furthermore, it is generally agreed by modern scholars that the only playwright among his contemporaries from whom Shakespeare seems to have learned very much was Christopher Marlowe ; and Marlowe was one dramatist who did make use of a formal symbolic "architecture" in his works.

Why then, in the teeth of an ever-increasing body of evidence, have Shakespeare scholars been so averse to taking account of this aspect of his art? Is it because it conflicts with a lingering wish still to believe in the sentimental image of Shakespeare as an «untutored genius» who «never blotted a line»? - He did blot lines ; and an alumnus of Stratford Grammar School was far from untutored. Is it the lingering pressure of the romantic Victorian notion that True Genius must, by definition, achieve its effects spontaneously, without premeditation ?-By now, we know far more than the Victorians ever did about the sheer volume of solid work that lies behind most strokes of genius. Yet : «as far as I am concerned», one eminent Shakespearean recently told an approving Stratford conference, «the more Shakespeare calculated, the less Shakespeare he».

How odd it would be if this were true : it would mean that Shakespeare, so alert in countless ways to the life of his own times, was yet completely out of touch with some of its basic æsthetic presuppositions. Let us look, then, at some apparent examples of Shakespearean «calculation» - asking, at the same time, whether it might not be of practical help to students if their attention was occasionally drawn to this aspect of Shakespeare's dramas ? With that extra question in mind, it may be useful to take first the structure of two favourite syllabus texts : The Tempest and Julius Caesar.

*

Though of course very dissimilar in other respects, The Tempest and Julius Caesar are both works with which students tend to experience the same sort of difficulty. Although in each case the main story-line may be grasped readily enough, many new students can do little more because for them each play exists only as a patchwork of scenes and episodes, whose very sequence it is found impossible to remember. The Tempest is seen as a distracting interweaving of four story-lines (those of Prospero, the lovers, the court characters, and Caliban and the low characters) together with the comings and goings of Ariel, the episode of the Harpies, and the Masque of Ceres. The atmosphere of magic, dissolving confidence in the normal reference-points by which we orient ourselves when mentally reconstructing a narrative, increases the uncertainty. The result is to create in 
retrospect a sort of delightful kaleidoscopic effect, of bright slivers of drama, loosely assembled. Yet when properly staged the play is not like that at all : what we then experience, is a fully-developed work of art, moving with a coherence and harmony whose satisfactions are close to those of music. InJulius Caesar, the difficulty comes with the second half of the play. The new student will have no trouble in perceiving a strong story-line up to the first counter-moves against Caesar's killers ; but is apt to feel that a mere clutter of material then fills out the rest.

In both cases however, simple diagrams or tabulations can greatly aid the student's struggle to get a better grip on the text. Many teachers, of course, are deeply suspicious of any use of diagrams in literary teaching, fearing that they can only foster a vulgarised, Procrustes-bed notion of the work in question. But these are theoretical worries : what damage has in reality been done, if the teacher points out to a class that has lost its way in The Tempest that the inner seven of its nine scenes are symmetrical from the final segment of I. ii through to the first segment of IV. 1, the penultimate scenes?

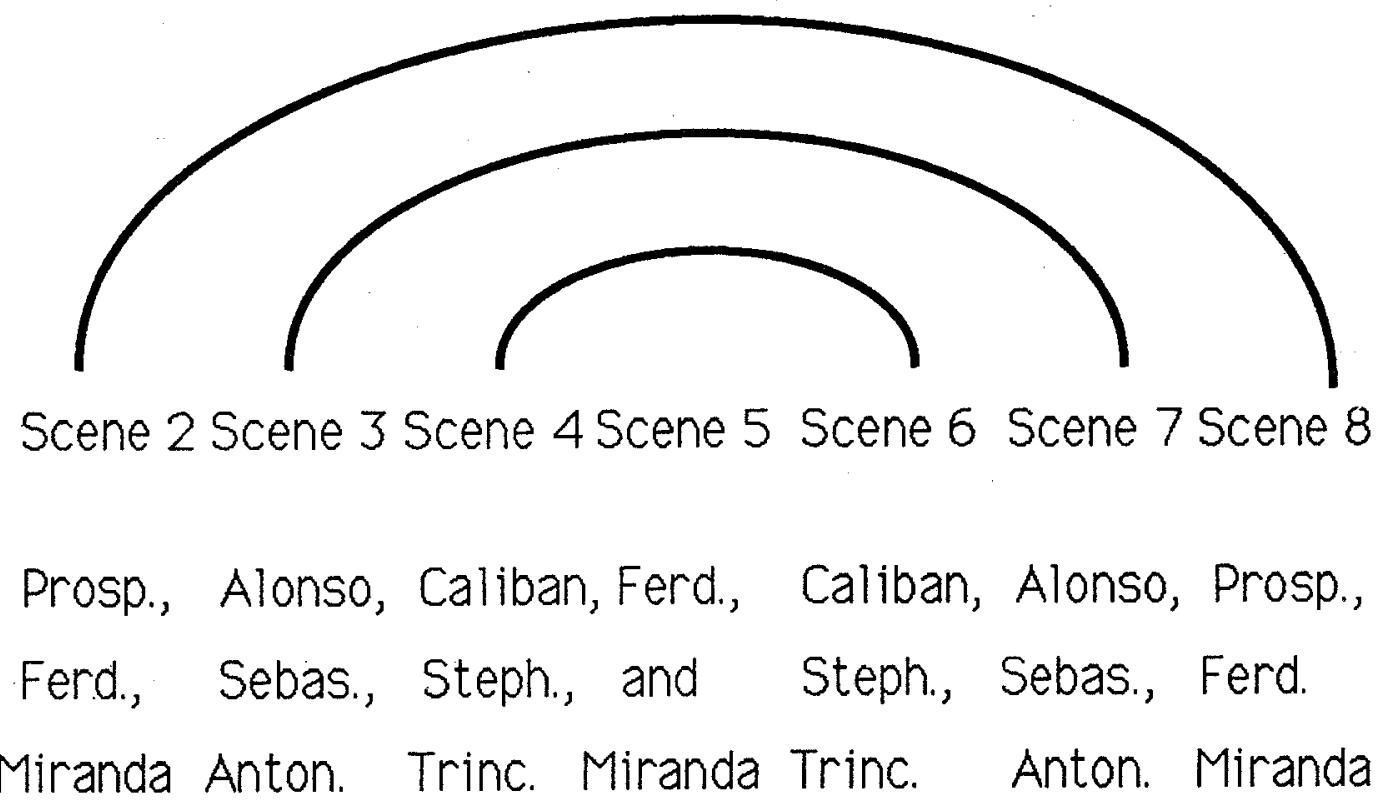

In the case of Julius Caesar, most students are told at some point that in some ways the play can be regarded as two successive tragedies : first, that of «the noblest man that ever lived in the tide of times» (Julius), and then that of «the noblest Roman of them all' (Brutus). But surely they can make much better use of that thought, when they also realise that these two halves of the play in fact form a repeated ABCDEFG:ABCDEFG scheme, hinged around the central Forum scene ${ }^{7}$ : 
First half of play

O of Pompey's cause.

Caesar and Antony

Brutus and Cassius

Brutus, Lucius, and Portia

Caesar close of Capitol scene
Fickle and disordered Roman street crowd ("Is this a holiday ?") celebrates destruction

Death of Caesar at the Capitol

Antony's private tribute to Caesar at
Second half of play

\begin{tabular}{|l|l|} 
A & $\begin{array}{l}\text { Second half of play } \\
\text { Fickle and now dangerous street crowd kills } \\
\text { Cimna, allegedly as friend of Brutus. }\end{array}$ \\
B & Octavius Caesar and Antony \\
C & Brutus and Cassius \\
D & Brutus Lucius, (and Portia) \\
E & Caesar's spirit \\
F & Death of Cassius and Brutus \\
(G) & Antony's tribute to Brutus
\end{tabular}

This tabulation is also useful in clarifying the century-old dispute (repeated in the case of Hamlet) as to which is the play's «central turning-point» : the Capitol or the Forum scene ? Most new students tend to be bemused by this dispute, since they haven't heard of R.G Moulton's pre-Bradleyan analyses of Shakespearean dramatic constuction", and don't see why it should necessarily be assumed that either play necessarily has a central tuming-point at all. And of course in many ways scepticism about this ancient critical squabble is well justified, since identification of the play's "centre" must vary with the way one reads it. If read as two successive tragedies - and the table above shows how the underlying structure of the play validates and reinforces this perception - then obviously the action "turns" in the Capitol, with Brutus stepping into the newly-vacant rôle of doomed leader almost before the blood is dry on his hands. But focus instead on the play as one work, dealing with the establishment of the Caesars as the keystone of the Romans' world, sanctioned by the Cosmos much as a true king in Shakespeare's day was regarded as God's viceregent, and it is equally obvious that the Forum scene is then the play's true centre. Neither way of seeing the play invalidates the other - and it seems significant (for Julius Caesar is a trustworthy text) that both the Capitol and the 
Forum scenes can claim to be physically central : the one lying across the half-way point of the text, and the other being the numerically central scene. This is unlikely to be accidental, since exactly the same thing occurs in Hamlet : here, too, the two scenes that modern criticism has intuitively identified as rival "centres" - the "Mousetrap" and the Closet scene - occupy just the same alternative mid-point positions in the Q2 text.

Again as in Hamlet, both of these rival central points in Julius Caesar are associated in true Elizabethan fashion with the idea of sovereignty : in the Capitol Brutus briefly inherits his victim's power, and at the Forum the Caesars regain it. This is strongly suggestive of the "mannerist" moral structuring that has been identified in various non-dramatic Elizabethan texts (where a first midpoint is associated with a falsely "sovereign" figure or concept : then discredited by the presentation of a truer sovereignty at a second central point, calculated on some other basis). However, in such works the discriminating reader is usually given an extra clue as to the identity of the truly sovereign centre by the build-up of a symmetrical "embellishment of the centre" around it. If Shakespeare had really been computing the design of Julius Caesar in a similar manner, would he not have done the same?

In fact he has done so. In the first place, it may be noticed that Shakespeare has altered his sources in order to arrange that Octavius, the new embodiment of Caesardom, shall enter Rome while the dead Julius, his wounds and Will made eloquent by Antony, is in the very act of sweeping Brutus and Cassius out of the city : nothing could better demonstrate a nascent dynastic continuity not only uninterrupted, but indeed created, by the assassins' act. It is tidily done : Antony's great performance is bracketed by the two announcements that Octavius is approaching, and then has already entered, Rome. But defter still is the use that has been made of the Cinna the Poet episode. Earlier this century, this scene seemed puzzling to some critics as a digression that advances nothing in the action. Nowadays it is "read" as a necessary demonstration of the effects of Antony's speech, that also offers a bitterly ironic commentary on what the conspirators' alleged desire to restore the health of the Republic has led to. But its double structural function should surely also be noted. By its echo of I. $i$, as we have seen, it initiates the re-run of the sequence traced in the play's first half. But it also serves to "frame" the Forum scene between two murders, of which it blackly travesties the first : Cinna dies for his mere name despite thrice insisting that he is not Cinna-the-conspirator, just as Julius is allegedly killed because «he would be crowned» despite having thrice refused a kingly crown. The parallel is underlined by the cynical joke about just tearing Cinna's name out of his breast and setting him loose : a mordant comment on Brutus' wish that he could kill the spirit of Caesar without shedding his blood.

In short, the essential design of Julius Caesar, consists of a twice-enacted narrative pattern neatly dovetailed into a symmetrically elaborated centre, emblematising, as it were, some of the main ideas of the play. Surely few would hold that a student's general grasp of this drama would not be helped by some understanding of that underlying scheme. 
To what extent a grasp of that aspect of this particular play also helps a more general understanding of Shakespearean drama, however, is another question. In the first place, it is necessary to make a broad distinction between three levels of construction/planning in Shakespearean drama (while the greatest of the comedies seem to lie outside the bounds of this discussion entirely, and follow quite other principles). On the basic level, Shakespeare is simply being human, in matters of design. As anyone in a crowded train or restaurant soon discovers, people tell stories all the time from their own experience ; and the general liking for filtering the picture of life one is offering through simple patterning and framing devices is unmistakable. Narrators persistently arrange things in threes, or juxtapose experiences in simple diptychs [it seemed a fine morning until I met Mr. B. Then I met Mr. C. and it was a fine morning again - a simple moral reflection then closes the tale]. They tend to like simple «X-shaped» plots [that old cat of a supervisor triumphs at the outset over the nice girl, who then in turn triumphs over her persecutor] or may arrange a longer narrative, in a rather Lear - like way, as a mounting succession of shocks or surprises - \&c., \&c. That a man so intelligent as Shakespeare tends throughout to observe this sort of fundamental tidiness - take for example the « $X$ shaped» plot of RichardII - is hardly remarkable ; and it is probably pointless to ask in any given case whether such simple symmetrising was deliberate or instinctive. At the intuitive level, this sort of basic planning-instinct would for example have been reinforced, for a bright child growing up in Elizabethan Warwickshire, by constant exposure to a wealth of oral literature'. Shakespeare's many allusions show how deeply folk-culture imprinted itself in him ; and the trick of strongly patterning (often symmetrising) material, as a mnemonic aid to performance, was engrained in the oral tradition ${ }^{10}$. At the more deliberate level, one has only to point to the habits of thought inculcated by Elizabethan schooling, with its training in the balanced, symmetrical and antithetical figures of rhetoric.

But it must be emphasised again that, at this basic level of literary planning, the cultural context in which Shakespeare worked did no more than reinforce constructional habits present in the literature of every age : their varying visibility, in different literary periods, is only the result of varying fashions in literary criticism or scholarship. Thus, it is easy to find reputable works by modern novelists - Virginia Woolf, Lawrence Durrell, and A.S. Byatt are three highly diverse examples - in which a crucially central episode or "turning-point" in the narrative is so placed as to lie astride the physical midpoint of the text $t^{11}$. (Two of the above authors have explicity confirmed to the present writer that they have consciously counted pages or chapter-sections to achieve this elegance : a fact which may perhaps help conservative Shakespeareans over the distaste they feel at the thought 
of Shakespeare similarly computing the proportions of his work). Yet what scholar or reviewer ever draws attention to this aspect of any modern work of fiction, unless it is obstrusively "experimental" in form ?

Another level of planning has been reached, however, as soon as any pattern, position or proportion in this kind of scheme takes on a specifically symbolic significance. Thus the underlying planning in The Tempest, illustrated above, can be just a piece of tidy Shakespearean craftsmanship ; but within the context of what has been shown about the Elizabethans' general habits of thought, and about the nondramatic literature of the period, it seems better seen as a characteristically intelligent Shakespearean game with the notion of the sovereign centre. The diagram offered earlier shows a triple frame around a central tableau of love : amor vincit omnia ; and Miranda even thinks she has disobeyed her father to declare her love. Yet this will be a royal union, and if love really were sovereign in that context, it would wreck the order of Court and State alike. So the scene is watched over by Miranda's royal father, and it is made clear that all is happening by his will - effectuated through a magic that is itself dependent, of course, upon a favourable conjunction of the heavens. [The scene is not only centric in relation to the rest of the play, but is internally centered also. The text is a good one, and the centre of III. $i$ is occupied by a matching pair of speeches from the lovers, of identical length (did Shakespeare really never "calculate" ?) of which the first ends at line 48 - in a 96line scene - with the whole bracketed by a repeated acknowledgement from Miranda that her father's word is no longer law for her. Ferdinand has, of course, been wanting to make Miranda «Queen of Naples» ever since he saw her ; but it is only at the start of this pair of speeches that he learns her name, and what follows is a little ritual to make clear that this - by the sexist standards of the age - is to be, the perfect love-match. Ferdinand makes clear that he is not without the male's requisite previous experience, in judging Miranda to be the-only-girl-in-the-world for him ; and Miranda then repeats directly to Ferdinand her earlier feminine assurances to her father that she does not need experience of other boys to know that this is the-onlyboy-in-the-world for her. (This licences the crescendo of joy in mutually avowed love which then rises through the second half of the scene). Meanwhile the symmetry of the matching pair of central speeches is extended, more diffusely, into what precedes and follows them : beforehand, Miranda tries to serve Ferdinand by carrying his logs for him ; after her speech, he avows his determination to serve her. The way of thinking that is exemplified in the construction of this scene is clearly continuous with the way of thinking manifest in the design of the whole play].

Symmetrical or centre-conscious planning, on either Level One or Level Two (as just defined) thus seems widespread in the canon of Shakespeare's work, and to have been much more specifically related to the actual physical proportioning or numerical division of the text than traditional criticism has grasped. Admittedly there are plays (All's Well That Ends Well is one) from which the signs of such planning seem to be absent without one sensing the presence (as in the greatest comedies) of some other elusive shaping principle ; and of course there are also plays 
(such as Love's Labours Lost) which would appear to have been so altered as to be outside the scope of this present inquiry. But more often, the question to be asked is whether the manifest element of symmetry in the planning of the work is likely to have been instinctive or deliberately calculated, or whether or not it carries a symbolic loading. Anyone who pays attention to the cleared-stage scene-divisions of A Midsummer Night's Dream, for example, will find in the layout of the Q1 text an obviously symmetrical plan that seems quite unsymbolic but elaborate enough to have required deliberate calculation. The symmetrical plan of Coriolanus ${ }^{12}$, on the other hand seems meant to follow and express in its own way the ideas embodied in the action of the drama. In Antony and Cleopatra Shakespeare has made the crucial battle of Actium the numerically central scene of the text, but the general structure of the play has still not yet been sufficiently explored for us to be sure quite how much follows from that particular piece of calculation on the dramatist's part ${ }^{13}$. Analyses of Macbeth suggest that even where a play has been substantially cut down in length, an attempt could be made to hack a rough approximation to an original sovereigncentered symmetry back into the text ${ }^{14}$. In all these cases, it seems clear that what we are concerned with is something that mattered to Shakespeare more than to his colleagues in the theatre. It would appear that he delivered scripts to his colleagues stamped with his own unique genius, yes, but scripts that were usually also solidly crafted in harmony with the normal æsthetic assumptions of the age, sometimes further embellished - when his mind had really been ignited by his subject - by those symbolic elegancies of structure that seem to have been part of the literary, not theatrical, taste of his times. The actors, like actors anywhere, then cheerfully chopped and bent his work into something that they felt would work better on stage. This can be seen particularly clearly in the Dream, where a subsequently-imposed act-division, manifestly connected with a preparation of the text for a later production, ploughs ruthlessly through the symmetrical layout of the cleared-stage sceneunits of the earlier text.

The surely very modest and unrevolutionary notion of Shakespeare ordering his plays in terms of what we have been calling Levels One and Two of constructional planning, has implications for the detective-work of Shakespearean textual scholarship. In the arguments such detective-work stimulates, it is frequently pointed out that Shakespeare did not necessarily compose his plays by beginning at line one, and then working steadily through to the end of the play. But though the point is generally accepted in the abstract, it is not a thought with which scholars normally seem able to do very much in practice. Yet surely the natural link is between the idea of non-sequential composition, and that of the symmetrical and centric planning which, in various forms, critics have been accepting in Shakespearean drama at least since the work of R.B. Moulton in the last century. Commonsense would suggest (and testimony from other writers confirms) that what is most likely to be left to be composed later, in works written on such a basis, is the "filler" between the main anchor-points of the scheme in question. Of course nothing conclusive can be proved on such a basis, but it is perhaps at least a consideration 
that should be cautiously borne in mind at times, when considering editorial problems in any Shakespeare play with a markedly regular structure. As evidence that Shakespeare did compose non-sequentially, there is of course the text of The Two Noble Kinsmen which he appears to have abandoned, for completion by another hand. It is noticeable that the parts of the extant play which seem most unequivocally Shakespearean come at the beginning, around the middle, and towards the end.

Earlier in this essay, however, there was reference to three levels of construction or planning that may be distinguished in Shakespearean drama. What is the third ? Here, we are not concerned, as before, with modes-of-design simultaneously or alternately present throughout Shakespeare's career as a playwright, but with traits apparent in some of his work for just a few years around 1600. At this time Shakespeare does appear to have been trying out the possibility of incorporating into his plays those constructional dramas and ironies, with their finesses between truly and falsely sovereign centre-points, consciously significant proportions, and occasional recourse to number-symbolism, that have been observed in some of the nondramatic compositions of the period.

The construction of one play of this period - Julius Caesar - has already been gone into in some detail here. As with Hamlet, it really does seem too much to believe that there can be no connection at all between the rival "central tumingpoints" that critics have discerned and disputed over (both of which occupy textual halfway points), and the equivalent configurations in non-dramatic texts. Nonetheless, the human brain is so extraordinary an instrument that it must be admitted that it is just possible that, even in Hamlet, (where the cleared-stage scene-units of the first two acts pair with those of the last two acts, in an ABCD......DCBA scheme) Shakespeare could have achieved this tidily elaborate kind of layout purely "by ear", in perhaps only unconscious imitation of something he had come to admire in the course of his reading. But the same argument is much less plausible in the case of another double-centered play, Henry $V$, where the symbolism implicit in the form seems much more elaborate.

When Shakespeare, for whatever reason, took on the task of dramatising the story of this hero-king and his battle, it must have been obvious from the outset that the meagerness of the material would cause difficulties. Compared with Shakespeare's other plays, the thinness of the basic plot is almost comic : the King goes to France, wins his battle, and goes home again. What, apart from distracting the audience (or reader) with a good deal of noise and bustle, could be done with that ? One thing that could be done, especially in a period when he seems to have been experimenting - with at any rate part of his mind - with the idea of viewing his play-texts as "mannerist" literary artefacts, was to draw upon the familiar Renaissance notion of the great general as a great artist, god-like in the capacity to take the confusion of war and battle, and order it according to his will. Listen to Henry the Fifth, says the Archbishop in the first scene, «and you shall hear a fearful battle rendered you in music». He is talking about the King himself, but he is also telling 
us precisely what the play of the same name is about to do.

Or so it would appear, if one counts the play's twenty-nine scenes ${ }^{15}$. (The dislike of so many Shakespeareans for counting lines, is very understandáble, and it is not suggested here that Shakespeare did so except in special circumstances. Even then, he may of course only have been making accurate eye-measurements of his manuscript pages, or simply have been guided by an innate sense of timing : after all, Beethoven was able to achieve the "Golden Section" proportion in some of his compositions purely by ear. But an aversion to Shakespearean «line-counting» need not require an equal aversion to the much more modest - indeed rather commonsensical - notion that, in composing his plays he would have been likely to count scenes). And what scene-counting demonstrates in Henry $V$ is a play laid out - fortuitously, many will say, but nonetheless with striking neatness - as a tetractys<smiles>C1#CCCCCCCC1</smiles>

If this is an accident, and that possibility must of course be allowed, then it was a notably happy one ; for the proportions of the tetractys correspond to the perfect musical consonances : (unison), fourth, fifth, (octave). Is it "to consider too curiously", to suggest that, from one point of view, unison is what the play is all about ? It begins with Henry stabilising the recently regained unity of the English by weeding out a handful of traitors and leading the rest agains the French. And it ends on a higher note of unison, with a merging of the kingdoms and royal families of England and France. But perhaps of more interest, especially in view of Shakespeare's repeated references in his works to the psychotherapeutic uses of music, is the fact that the "fourth" and "fifth" were considered to represent the ideal relative proportions of the rational, irascible and concupiscible faculties in the truly harmonious soul. It is precisely these aspects of Henry's own character that the play foregrounds. - «May I with right and conscience make this claim? «I was not angry since I came to France, until this instant». «I love France so well that I will not part with a village of it; I will have it all mine».

But of course everything said in the last paragraph depends on making good the assertion that Henry $V$ is analysable in terms of the divisions of the tetractys. Certainly, the play's halfway point has been turned into a characteristically "sovereign" centre ; for it is in the (numerically central) fifteenth scene of the play that King Henry at last receives the formal defiance of the French king. As in Julius Caesar, the play further enhances this midpoint by really extending the episode into a centre-piece consisting of three scenes : first we see the despatch of the French herald, then Henry's rebuff of the defiance, then the French waiting to arm for the fight that must follow after Henry's response to the herald. Then at the one-third and two-thirds points in the text (tenth and twentieth scene) we find those two astounding jets of heroic verbal energy by which Henry seems to secure victory at Harfleur and Agincourt almost single-handed : «One more unto the breach» and the Crispin Crispian speech. Dividing the play into quarters, are the landmarks in the progress of the unfortunate French court. After the Prologue, six scenes elapse 
before they determine to «fill the proportions (sic) of defence» - i.e., to order their defences; then another six scenes elapse before their King's defiance is delivered ; then after a further six scenes, hope lost, they cry «the devil take order now». But through all this runs the regular pulse of Henry's successes, effecting its own fivepart segmentation of the drama: 6th scene, conspiracy crushed; 12 th scene, Harfleur taken ; 18th scene, Henry wins his argument with his men ; 24th scene, victory at Agincourt is conceded.

There is of course another five-part scheme in the play. Although it has increasingly become the view of modern editors that the speeches of they Chorus in Henry $V$ are essentially to be viewed as scenes like any other, the still mark out a five-act scheme. When viewed in this way, of course the play then has another halfway point : the numerically central scene not of the whole play, but of Act III, the central act. This is the charming interlude of the Princess Katherine's English lesson. It is difficult to believe, in the context of what has already been noted here about other Shakespeare plays, and about Elizabethan centric-consciousness generally, that this positioning of Katherine is quite free of symbolism : in short, here again, as with Julius Caesar and Hamlet, is a play with an ironic interplay of implications between two alternative 'sovereign' centrepoints, with the one 'truer' than the other.

Once again the traditional critical debate about the play is the pointer to its constructional strategy. True, we do not in this case see a long-standing wrangle about rival «central turning-points»: we could not, for the play's simple line of action does not «turn» at all, but marches straight on to its conclusion, with Katherine herself no more than an essentially passive - if willing - sacrifice to the victor. But what we do have, is a long-standing critical dispute as to whether the play is really belauding Henry and his achievements, or covertly passing a quite severe judgement upon them?

Yet Empson long ago taught us to ask Why Not Both? When faced with such critical disputes ; and surely that is the right question in this case. And in such an essentially static drama, where form is in any case likely to take on at least some sort of emblematic aspect, it would be natural enough for the two ways of seeing the moral issues raised by the play to be related to the two ways of seeing the play's organisation. [That Shakespeare did build two alternative structural schemes into the play, is evident from the fact that the Chorus/act divisions cut through the symmetrical layout of the main action, yet are not (unlike in the Dream) a later addition to the text].

It should be noted, then, that Katherine is the real victor in the play. Henry has not really conquered France, for his empire will disappear within a generation. But Katherine has conquered England, for after Henry's death she will become the mother of the Tudor dynasty, as any educated member of an Elizabethan audience would presumably have been well aware. Apart from her parents (and, embarrassingly, the traitor Earl of Cambridge, whose latent royalty is however wholly concealed in the play) she is the only ancestor of Elizabeth I among all these 
confidently brawling mediaeval princes. The irony is clear. The whole play, alike in terms of idea-content and of textual layout, seems organised around the Mars-like triumphs of King Henry. Yet it is gay, innocent little Katherine, quietly enthroned at the alternative, secondary-seeming midpoint of the play, in a scene so ostensibly unimportant that it can even be in a foreign language, from whose loins the real future will grow, once this vainglorious, brutal mediaeval brawling is over. If one accepts the Elizabethan association of the midpoint with the idea of sovereignty at all, the implicit judgement here seems clear.

By the time Shakespeare had completed Hamlet, however, his curiosity about the applicability of elaborately symbolic modes of mannerist literary construction to writing for the stage seems to have burned itself out. In Othello, and King Lear, although there are clear signs that a reflective curiosity about constructional issues still persists, it is much more Elizabethan theories of dramatic, rather than literary, composition that appear to be engaging his speculative intelligence ${ }^{16}$. But that is another story - or rather, another chapter of the same story, which remains that of a renaissance artist whose dazzlingly various compositions may be for all time ; but whose pratical compositional habits were much more of a piece with the general practice of his own age than we, in our bardolatry, sometimes care to acknowledge. 


\section{NOTES}

1 HIEATT, A. Kent, Short Time's Endless Monument, New York, 1960.

2 A useful showcase of work of this kind is Silent Poetry, ed. A. Fowler, London, 1970.

3 McALINDONThomas, «Thenumbering of Men and Days : Symbolic Design in Julius Caesar», Studies in Philology LXXXI, 372-94. [Like many studies of its kind, this essay pushes too hard and too far ; but its exploration of the quiet play that seems to be made in the drama around the number 8 (the number of Regeneration) and the name of Octavius must give any fairminded reader pause, and is not inconsistent with other aspects of the construction of the tragedy noted here].

4 The Works of Michael Drayton, ed. J.W. Hebel. 5 vols. Oxford, 1961, See Vol. II, pp. 3-5.

5 ERIKSEN R.T., The Forme of Faustus Fortunes, New Jersey 1987.

6 ROSE Mark, Shakespearean Design, Harvard, 1972. The diagram reproduced here is on p. 173.

7 The analysis of Julius Caesar offered here is a conflation and expansion of points made by the present writer in Essays in Criticism XXVII, 1977, pp. 6-7, and by Prof. Kristian Smidt in his Unconformities in Shakespeare's Tragedies (publication pending).

8 MOULTONR.G., Shakespeare as a dramatic artist, Oxford, 1885. The enlarged Third Edition, (1893) will be found more useful.

9 As late as the 1920s, in an area only $40 \mathrm{~km}$ from Stratford-on-Avon, it took one collector only nineteen months to record over 600 ballads and folksongs, some over 400 years old. These were only the remainder of a rich tapestry of seasonal feasts and festivals, folk plays, folk tales, \&c., \&c., that survived largely intact well into the last century. Most Elizabethan Londoners had contact with this world.

10 BUCHAN David, The Ballad and the Folk, London, 1972.

11 Mrs Dalloway (Woolf), Tunc (Durrell), and The Game (Byatt) all illustrate the point.

12 WAKEMAN, Carolyn Grant, Action and Interpretation : the impact of Coriolanus in the theater, Ph. D thesis, Washington University, 1981. See ch. 1.

13 BATTENHOUSE Roy, Shakespearean Tragedy : its Art and its Christian Premises, Bloomington, 1969.

14 GODSHALK William, Patterning in Shakespearean Drama, The Hague, 1973. See especially pp. 118-9.

15 If one counts the speeches of the Chorus as scenes, as does the new Oxford edition - with the implicit blessing of other editors (see for example the comment on this subject in the Pelican edition) - then there are 29 scenes in the play, although of course the conventional numbering shows a lower total.

16 Attention is drawn to an article by Keith Brown in Cahiers Elisabethains, oct. 1982 : "Chimeras dire, An analysis of the "conflated" Lear text". The author would today stand by the main points made in this article ; but wish to revise extensively many points of detail and secondary argumentation. 